\title{
EVALUATING THE APPROPRIATENESS OF GRAMMAR ACTIVITIES IN DEVELOPING GRADE ELEVEN STUDENTS' ENGLISH ORAL COMMUNICATION SKILLS: EVIDENCES FROM ETHIOPIA
}

\author{
Abebe Asres Mengistu \\ PhD, Assistant Professor of Applied Linguistics and Communication, \\ Department of English Language and Literature, \\ College of Social Science and Humanities, University of Gondar
}

DOI: $10.37648 / \mathrm{ijrssh.v10i01.039}$

Received:15 ${ }^{\text {th }}$ November 2019; Accepted:12 ${ }^{\text {th }}$ December, 2019; Published:06 ${ }^{\text {th }}$ January, 2020

\begin{abstract}
The main objective of this study was to evaluate the appropriateness of the grammar activities in grade eleven English for Ethiopia students' textbook in developing students' oral communication skills. So as to achieve the intended objectives, the grammar tasks were identified and analyzed based on Nunan's (1989) model. The data for the study were collected by the means of document analysis, students' questionnaire and teachers' interview. The students' textbook, forty students and six teachers from Shinta General Secondary and Preparatory School were randomly selected as sources of data for the study. As the findings of the study indicated, the objectives of the grammar tasks are stated explicitly in a way that students could understand them easily. However, most of the objectives are not found as expected because of lack of variety and repetition. Though the grammar activities are appropriate to the goals of the tasks, most of the inputs in the textbook are not authentic and motivating. Most of the grammar tasks are also designed to be done in the classroom as well as outside the classroom setting but they are inappropriate for pair/group work to allow students to actively participate in-group. Moreover, the grammar tasks in the textbook are integrated with the other language skills. Most of the grammar tasks in the textbook are not the level to encourage language use/meaning rather they are focusing on form/structure. It was also found out that grammar activities in the textbook are giving little attention for pair and group work, and the activities are not at the level to encourage students' participation and develop their oral communication skill. Based on the conclusion, it is recommended that English textbook writers should take in to consideration the basic components of the tasks, nature of the grammar tasks and the appropriateness of grammar tasks in improving students' oral communication skills. Further, teachers have to play their role effectively by making some adjustments on the grammar tasks to fill the gaps.
\end{abstract}

Key Words: Evaluation, Appropriateness, Grammar activities, Oral communication skills 


\section{INTRODUCTION}

Grammar is one of the most important imputs English language teaching because it is a means by which messages are organized to convey meaningful information. According to Ellis (1997) grammar teaching is one of the elements of language learning which develops the oral communication skills of the students. Without the knowledge of grammar, students will not be able to develop their oral communication skills. Including communicative grammar tasks in English textbooks will promote the students' oral communication skills. Grammatical competence, along with socio-linguistic strategic competency, is seen as crucial for mastering communicative competence. Nunan (1991) states that "Grammar is an important instrument of communication, and a text cannot be written cohesively without paying attention to how meaning is expressed through grammar." In this view grammar, lexis and phonology are resources for creating meaning in social communication. Besides, having the knowledge of grammar is important means of achieving linguistic accuracy, the more accurately a message is conveyed, the lesser the opportunities for misunderstanding in communication. Ellis (1997) argues that recent research results on EFL/ESL learning show that without grammar instruction learners frequently fail to achieve advanced level of communicative competence. It is, thus, crucial to include grammar in language curriculum through communicative tasks. White (1987) states that communicative grammar tasks can improve the quality of Second/Foreign language learning/teaching. These scholars also noted that grammar tasks should include games, role-plays, simulation, pair works, group works, information gap and problem solving activities that would enhance students' oral communication skills. Nunan (1991) claims that tasks are basic building blocks in many language teaching activities from either a language acquisition or a communicative perspective. Therefore without it, it is not possible to enable students to produce grammatical sentences and when and how to use them (Celce-Muricia, 1991).
Similar studies have been conducted. For example, Hailu (2008) conducted a study on the English for Ethiopia grade eleven students' textbook Book 1 and 2 and his findings indicated that the design and the layout of the textbooks lack variety and the cover of the textbooks are nor attractive and durable. Tiglu's (2008) study focuses on appropriateness of communicative grammar teaching at grade 10 and he found out that majorities of the grammar lessons are mechanical and follow the traditional approach of grammar teaching, Wodajo (2014) studied theevaluation of grammar lessons in grade 10 English textbook in terms of developing students' communication skills. His finding show that majority of the grammar lessons are gap filling mechanical lessons and his study emphasizes on evaluating all grammar lessons of grade 10 textbook in terms of developing students' communication skills, but this study focuses on evaluation tasks of the new grade 11 English textbook. This study is,therefore, different from the above mentioned researchers for the main reason that the current research is based on evaluation of grammar tasks in grade 11 new English textbook in relation to students' oral communication skills.

\section{RESEARCH QUESTIONS}

- To what extent do the grammar tasks in grade eleven-text book meet the criteria ?

- What are the views of teachers regarding the appropriateness of the grammar tasks in textbook?

- How do students perceive the way the grammar tasks are designed in the textbook?

\section{RESEARCH METHODOLOGY}

\section{Data Sources}

The major data source for the study was grade 11 English Textbook and the syllabus of grammar tasks. The textbook is selected because it is a relatively a new text book under practice. According to Chambers (1991), evaluating a textbook is important if it is collectively undertaken by everyone involved in the teaching and learning process. Teachers and 
students of grade eleven in the sample school were also sources of data used to substantiate the data taken from the text book.

\section{Sampling Size and Sampling Techniques}

The main data source was the grade eleven English textbook. In this textbook, grammar tasks were selected for evaluation. There were a total number of three hundred ten students in six sections in the school. From these sections 3 of them were social science while 3 of them were natural science. In social science stream there were 160 students while 150 students were in the natural science stream. Accordingly, eighteen students from Natural Science scream and Twenty-two students from Social Science stream were selected by using simple random sampling technique. Then the questionnaire was distributed to forty students. In the sample school, there were six English language teachers who teach grade 11 students. Using comprehensive sampling technique, all of them were included in the study.

\section{Instruments of Data Collection}

In order to achieve the objectives of the study, three instruments of data collection-content analysis, questionnaire, and interview were used. The major instrument used in the study is content analysis or grammar tasks evaluation. To validate the content analysis, questionnaire and interview were conducted with students and teachers respectively to see their perceptions of the appropriateness of grammar tasks included in the textbook.

\section{Content Analysis}

Evaluation of grammar tasks (content analysis) is the major data-gathering tool in the study. Textbook evaluation is one of the types of evaluation research in which the researcher selects some significant characteristics and observes the extent to which they happen( ). Accordingly, this method enables the researcher to evaluate whether or not the grammar tasks in grade 11English textbook is designed in developing the students' oral communication skills. To attain this, the researcher used the grammar tasks evaluation checklist. The checklist was employed using the integration of checklist method and in depth method of textbook evaluation strategy. Therefore, all the grammar tasks in the textbook were evaluated and categorized according to their characteristics based on a set of criteria.

\section{Interview}

In this study, semi -structured interview was employed. The main purpose of the interview was to get evidences from teachers regarding the appropriateness of grammar tasks presentedin the textbook and to substantiate the data obtained from textbook evaluation.

\section{Questionnaire}

Cunnings worth (1995) and Tomlinson (1998) suggested that in order to determine the relative strengths and weakness of a textbook and ultimately decide how well it suited the desired and attainable goals of the learners series of textbook evaluation survey questionnaires should be used. The questionnaire contains questions that are pertinent to the practical considerations, design, instructions, skills integration, presented in the textbooks.

\section{Methods of Data Analysis}

To analyze the collected data, both qualitative and quantitative analysis methods were employed. Mixed type of data analysis increases the validity of the findings. These methods of studies use two or more different data collection techniques that can improve the validity of the research (Johnson,2003). First, the data obtained through text book evaluation was counted. The frequencies were converted into percentage. In addition, the appropriateness of the grammar tasks were described and discussed in words in relation to develop the students' oral communication skills taking some examples of grammar tasks from the textbook. Second, the data obtained by the means of questionnaire were analyzed in quantitative terms. Finally, the data gained from teachers' interview are analyzed thematically based on the interview questions mentioned in the interview protocol. 


\section{DATA ANALYSIS AND DISCUSSION}

\section{Evaluating the grammar activities in terms of motivation}

motivation is some kind of internal drive that encourages somebody to pursue a course of action. If we perceive a goal and if that goal is sufficiently attractive, we will be strongly motivated to do whatever to reach that goal (Harmer, 1991). Motivation is the most important factor affecting success in language learning. For example, if students are highly motivated, they will succeed regardless of the methods used or the circumstances in which they study (Larsen-Freeman, 2001). Therefore, to achieve this, topics of grammar tasks need to be highly attractive and appealing that can win the students' interest, and drive them to work on. Some of the grammar activities' topics in the textbook seem to appear familiar to the students, and the activities more or lees tried to motivate them. For instance, the grammar activities under the section of unit1, page 14,23, 24 and students are asked to read the dialogue. Four classmates are having a conversation during break. For example,

Masantu:

Abdisa:

Masantu:

Abdisa:

They read the dialogue about some of the interesting, happy, sad, funny etc from the given activities. This kind of grammar activities help students to think actively and students can be motivated because they were asked to read, write, and speak/ communicate freely whatever things come in their mind and it is familiar to them. It says like:

\section{Extract 1}

Work in-group of threel four students. Look at the list of opinions below. Discuss each one using the language of discussion in your table.

In the following example (unit 2, page 32), the students were also asked to do discuss on the given figure.

Extract 2

With a partner, discuss how to complete each table with the figures below each one.

Table1: Enrollment rates at primary level in percentage

\begin{tabular}{|l|l|l|l|}
\hline Year & Male & Female & Total \\
\hline 2003 & & & \\
\hline 2004 & & & \\
\hline 2005 & 67 & & 63 \\
\hline 2006 & 72 & & 69 \\
\hline 2007 & 79 & & 76 \\
\hline 2008 & & & \\
\hline
\end{tabular}

Source: United Nations Statistics Division 2010

Table 2: Enrollment rates at secondary level in percentage

\begin{tabular}{|l|l|l|l|}
\hline Year & Male & Female & Total \\
\hline 2003 & 26 & & \\
\hline 2004 & 28 & & \\
\hline
\end{tabular}




\begin{tabular}{|l|l|l|l|}
\hline 2005 & & & 25 \\
\hline 2006 & & & 29 \\
\hline 2007 & 38 & & \\
\hline 2008 & 39 & & \\
\hline
\end{tabular}

Source: United Nations Statistics Division 2010

In this type of grammar activity, students are highly motivated to do the given grammar activities accordingly. It tried to foster them because it is based on interesting figures or graphic data. Graphic data, table, charts, illustrations, and picture data are very important to arouse their interests and needs, and engage students to do activities. As much as possible to keep students engaged in grammar activities, there has to be some interesting topics that motivate them rather than simply putting instructions only (Harmer, 1991).

However, fromforty three grammar activities that are found in the textbook, thirty grammar activities asked to write the form of the verb with the same topics repeatedly. Students sometimes bored with engaged in such grammar activities. This might be because of some of the topics under the grammar sections of some of the units are repeated and less appealing to win the learners interest focusing on real communication and integrated with other skills.

For instance, topics like, "Complete the sentences with the correct form of the verb in the brackets" and "write the correct form of present perfect, past perfect and -ing form" are repeatedly presented under the grammar sections of each unit(1-12). When the activities are repeated here and there, they may lead students to lack of motivation from active engagement in doing any activity. Without sufficient motivation in the activity, even individuals with remarkable abilities cannot accomplish long-term goals (Larsen-Freeman, 2001). Most studies show that the effect of motivation have found a relatively strong correlation between motivation and language learning success, and more importantly, motivation is the most significant predictor of achievement in language learning.

\section{Evaluating the grammar activities in terms of the integration of other skills}

Integrated-skills teaching, which refers to the linking of the macro language skills(listening, reading, speaking and writing) and language elements ( grammar and vocabulary) in language teaching/learning process is widely practiced in many countries of the world nowadays). In real life communication situation outside classroom and in a classroom language learning process, students rarely use only one skill. Students use integrated-skills when they learn a language. Due to this, two or more language skills should be interwoven and presented in context for second language learners (Harmer, 1991). In English for Ethiopia grade 11 textbook, from forty three grammar activities, thirty five grammar activities were integrated the four macroskills as evident in the following activities.

Extract 3
1. "Read the dialogue. Four classmates are having a conversation during break." (Unit 1, page 14)

2. "Read this dialogue. It takes place in a school classroom, first thing on Thursday morning." (Unit 2, page 40)

3. "Go back to the increase your word power: medical treatment section above. Student " $A$ " should have the book open and ask student " $B$ " to give a definition of one of the medical staff or a piece of medical equipment." (Unit 3, Page 62)

4. "Talk about what your mother lother family member used to do in the following situations, when you were a small child, use used to and would where possible." (Unit 3, page 80)

5. "Write past conditional sentences about something you regret in your own life beginning If I had.... If I hadn't....." (Unit 3, page 84)

6. "Complete these sentences from the listening text with the correct form of verbs in brackets." (Unit11, page 279) 
In the six instructions listed above, one can understand that there is an integration between reading, listening writing, speaking, word power and grammar so that students can get an idea from the reading text, speakingand listening to build their grammar in terms of developing oral communication skills. The evidence in number six also shows how grammar and listening are integrated to help students with additional material.

\section{Evaluating the grammar activities in terms of eliciting real communication}

Since language classrooms are intended as preparation for survival in the real world and since real communication is a defining characteristic of CLT, an issue which soon emerged was the relationship between classroom activities and real life. Some argued that classroom activities should as far as possible mirror the real world. Real world tasks are those that have been produced in the course of genuine communication and not specially designed for language teaching purposes only.

In grade 11 English textbook, there are forty-three grammar activities, from such activities eleven of them were constructed in terms of eliciting real communication. As it can be seen in thefollowing extract taken from the textbook, the grammar activities were found to be authentic which means the activities that elicit real world communication.

\section{Extract 4}

"Work in a group of three/four students. Look at the list of opinions below. Discuss each one using the language of discussion in your table"(Unit 1, page 24)

Discussion in diagrams, tables, pictures and etc are very important to be used genuinely by the students inside/outside the classroom when they are studying/learning, expressing their idea and engaged on other subjects. Students use tables, figures, and diagrams in many ways in their day to day activities. For example, when they want to reflect ideas for any kind of speaking like dialogue, talk, games and grammar like a story, etc. In addition, when they are not sure of the sequence or order of their ideas (for example, in making dialogue, debating, coherence, in form filling or assignment writing and etc.), a table or diagram is a good way of showing them down a direction. When students are familiar with tables/diagrams, it helps them in many ways.

\section{Extract 5}

"Work with a partner or in a small group. Discuss the situation now. Do you think the figures are very different from those in 2008?" (Unit 2, page 32)

Here the students are asked to discuss on the situation, to think, to talk, to report about the information given in the figures and oral and written reports and discussion on their own skills respectively. These kinds of grammar activities are not limited in the classroom only but they are very open or common to be done outside the classroom. For example, discussion/report are very common for this grade level student (grade 11). Students can be asked to discuss, to prepare oral and written reports on what they have done or watched in the diagram, picture, table, figures as well as what they have observed in the site observation. An attempt to link classroom language with language activities outside the classroom is one of the features of task components (Nunan's, 1991.). Therefore, these kinds of grammar activities are very important in order to elicit the use of the target language outside the classroom.

Extract 6

1. "Use the structure $a-j$ in the table above to construct a two-line dialogue for each of these situations. In the first line person " $A$ " asks for advice, in the second line, " $B$ " gives advice. Use the variety of structures from the table." (Unit 4, page 99)

I have cut my finger very deeply.

A: I have cut my finger very deeply. What shall I do?

B: You had better put a tight bandage around it and hold it up to stop the bleeding.

"Describing places and activities persuasively" (Unit 5, page 123) 
This grammar activity also tried to engage students in real world communication. In this activity, students are asked to make a two-line dialogue on asking and giving advice and describing places found in Ethiopia by using variety of structures from the table. So such kinds of activities will expose students to real communication outside the classroom. Regarding this, Richards (2003) states that the linkage of classroom language learning with language outside the classroom is one of the principles and practices of task based language teaching. Thus, the grammar activities above are helping students to improve their oral communication skills.

There are also some other grammar activities in the textbook which engage students in real world communication outside the classroom. For example, on page 14 ,unit 1 ; page 32 , unit 1 ; page 42 , unit 2 ; page 99 , unit 4 , page 123 , unit 5 , page 145 , unit 6 , and page 151, unit 10 students were asked to work within a partner on the table, diagram and figure. On the other hand, working with the partner and making dialogue is not only a classroom activity but also the activity that students are performing in their day-today activities outside the classroom.

Generally, out of forty-three, eleven grammar activities in the textbook were found to be eliciting real world communication outside the classroom. The classroom grammar activities should as far as possible mirror the real world and use real world language (Harmer, 1991). So it is possible to conclude that more grammar tasks should be designed as close to real life tasks as possible and promote language use.

\section{Evaluating the grammar activities in terms of} their meaningfulness

Grammar activities should also be designed in a way that they engage learners in a meaningful and authentic language use rather thanthey merely promote meaningful practice of language patterns/language form. In classes where Communicative Language Teaching is practiced, students' attention is not on the code of the language, but on the meaning (Nunan, 1989). In the textbook most of the grammar activities provided are meaningful to the students. The following are examples taken from the text book:

Extract 7

1. "Work in a group of three/four. Look at the list of opinions below. Discuss each one using the language of discussion in your table" (Unit 1, Page 24)

2. "Work with a partner or in a small group. Discuss the situation now. Do you think the figures are very different from those in 2008"(Unit2, 32)

3. "Work with a partner. Student " $A$ " should have the book open and ask student " $B$ " to give a definition of one of the medical staff or a piece of medical equipment" (Unit2, page 65)

4. "Talk about what your mother/other family member used to do in the following situations, when you were a small child, used to and would where possible" (Unit 3, page 80)

5. "Construct two-line dialogue for each of these situations. In the first line, person " $A$ " asks for advice, in the second line, person " $B$ " gives advice use the variety of structures from the table" (Unit 4, page 99)

Example: I have cut my finger deeply.

A: I've cut my finger deeply. What should I do?

B: You'd better put a tight bandage around it.

1) I've got a headache.

A:

$B$ :

2) I feel tired.

A:

$B:$

3) I don't know what to do. My boyfriend wants me to have sex with him.

A:

$B:$

6. "work in a group of threelfour and play this game” (Unit 11, page 261)

Here also, the textual evidence taken from the textbook above shows that students are asked to discuss using the language of discussion in a group about opinion from the table, to ask and give definitions of medical equipments, to give an opinion, give figures, to talk about mother or other family member, to ask and give an advice and to play 
a game with people some. Such kinds of grammar activities would help studentsget the exposure to express their ideas freely focusing on meaning rather than form of the language without context.

In addition, the activity shown above clearly depicts the feature of a communicative task since the components of the task is a piece of classroom work which involves learners to comprehend, manipulate, produce and interact with the target language while their attention is principally focusing on meaning rather than form (Nunan, 1989)
Evaluating the grammar activities in terms of the suitability of tasks for pair/group work

Most of the classroom activities reflected in Communicative Language Teaching should be designed in a way to becarried out in pairs or small groups. When students work in pair or small group to talk and write about something, every student in the group would get a chance to contribute his/her, part either in generating ideas or in correcting grammar item so that their oral communication skills will be improved. Thus, the grammar should preferably be fair for pair or group work.

Table3: the number of grammar activities suitable for pair/group work

\begin{tabular}{|l|l|l|l|}
\hline \multirow{2}{*}{ Units } & \multicolumn{3}{|l|}{ Number of grammar activities suitable for: } \\
\cline { 2 - 4 } & $\begin{array}{l}\text { Individual } \\
\text { work }\end{array}$ & Pair/group work & Total \\
\hline One & 4 & 1 & 5 \\
\hline Two & 3 & 1 & 4 \\
\hline Three & 7 & 1 & 8 \\
\hline Four & 2 & 0 & 2 \\
\hline Five & 2 & 1 & 3 \\
\hline Six & 4 & 0 & 4 \\
\hline Seven & 2 & 0 & 2 \\
\hline Eight & 5 & 0 & 5 \\
\hline Nine & 4 & 0 & 4 \\
\hline Ten & 3 & 0 & 3 \\
\hline Eleven & 2 & 0 & 4 \\
\hline Twelve & 3 & 0 & 3 \\
\hline Total & 41 & 4 & 45 \\
\hline$\%$ & 91.1 & 8.9 & $100 \%$ \\
\hline
\end{tabular}

As it can be seen from table 4.1 above, $8.9 \%$ of the grammar activities in the textbook promote the use of pair or group work while $91.1 \%$ of them encourage the use of individual work while the reverse is true that is $9.1 \%$ of the grammar activities in the textbook needs to be done in in individual thaninpair/group. Therefore, less consideration is given for group participation of grammar activity in the grade $11^{\text {th }}$ students' textbook. Let us see also see some few examples from the textbook:

Extract 8

"Complete these sentences so that they are true for you" (Unit 3)

"Choose the correct form of the verbs in each of these sentences" (Unit 1)

"Try to identify rules of use for the word 'like' and 'as' (Unit 8)

"Choose this rule with 'can' 'could' 'able to' (Unit 9) 
As can be seen in the extract eight above, the grammar activities in the textbook do not seem to be suitable for open pair/group work. This implies that the grammar activities have little contribution in developing students' oral communication skills.

Table 4: Students' responses on the appropriateness of grammar tasks

\begin{tabular}{|c|c|c|c|c|c|c|c|c|}
\hline $\mathrm{NO}$ & Items & & $\mathrm{SA}(5)$ & $\mathrm{A}(4)$ & $\mathrm{U}(3)$ & $\mathrm{D}(2)$ & $\mathrm{SD}(1)$ & Total \\
\hline \multirow[t]{2}{*}{1.} & \multirow{2}{*}{$\begin{array}{l}\text { The grammar activities are } \\
\text { motivating to me because it considers } \\
\text { my needs and interests. }\end{array}$} & & 4 & 3 & 3 & 9 & 21 & 40 \\
\hline & & $\%$ & 10 & 7.5 & 7.5 & 22.5 & 52.5 & 100 \\
\hline \multirow[t]{2}{*}{2.} & \multirow{2}{*}{$\begin{array}{l}\text { The grammar activities are integrated } \\
\text { with other language skills }\end{array}$} & & 24 & 14 & - & 2 & - & 40 \\
\hline & & $\%$ & 60 & 35 & - & 2.5 & - & 100 \\
\hline \multirow[t]{2}{*}{3.} & \multirow{2}{*}{$\begin{array}{l}\text { The grammar activities are authentic } \\
\text { in eliciting real communication by } \\
\text { allowing us to use language outside } \\
\text { the classroom }\end{array}$} & & 1 & 2 & 2 & 15 & 20 & 40 \\
\hline & & $\%$ & 2.5 & 5 & 5 & 37.5 & 50 & 100 \\
\hline \multirow[t]{2}{*}{4.} & \multirow{2}{*}{$\begin{array}{l}\text { The grammar activities are designed } \\
\text { to teach meaning rather than } \\
\text { language forms. }\end{array}$} & & 18 & 13 & 2 & 5 & 2 & 40 \\
\hline & & $\%$ & 45 & 32.5 & 5 & 12.5 & 5 & 100 \\
\hline \multirow[t]{2}{*}{5.} & \multirow{2}{*}{$\begin{array}{l}\text { The grammar activities in the } \\
\text { textbook are suitable or allowing us } \\
\text { to discuss in pair/group and } \\
\text { individually }\end{array}$} & & 4 & 5 & 1 & 19 & 11 & 40 \\
\hline & & $\%$ & 10 & 12.5 & 2.5 & 47.5 & 27.5 & 100 \\
\hline
\end{tabular}

Keys: $\mathrm{SA}($ strongly Agree $)=5 \quad \mathrm{~A}($ Agree $)=4 \quad \mathrm{U}($ Undecided $)=3 \quad \mathrm{D}$ (Disagree) $=2$

$\mathrm{SD}($ Strongly Disgree $)=1$

As it can be seen from table 4.2 above, for the item $1,10 \%$ and $7.5 \%$ responded strongly agree and agree respectively while $22.5 \%$ and $52.5 \%$ responded disagree and strongly disagree. The remaining $7.5 \%$ replied unable to decide. From this result, we can understand that the grammar activities are not motivating to the students as well as are not considering their needs and interests.

On item 2, 60\% and $35 \%$ respondents have responded strongly agree, agree and $5 \%$ respondents express disagree and almost all (95\%) of the respondents have agreed with as there is an integration of grammar with other language skills. Based on this, it is possible to say that the grammar activities are appropriately integrated with other language skills.
With regard to the authenticity of the grammar activities in eliciting real communication, $50 \%$ and $37.5 \%$ of them respondeddisagree and strongly disagree respectively for the total of $87.5 \%$. while $5 \%$ and $2.5 \%$ have responded agree and strongly agree respectively, and 5\% didn't want to say anything. From the result, it is possible to deduce that the grammar activities are not authentic in eliciting real communication in allowing students to use the language outside the classroom.

Students were also asked questions concerning whether the grammar activities are designed to teach students meaning rather than form of the target language.Accordingly, more than half of the respondents $(78 \%)$ replied they do agree whereas $17.5 \%$ replied that they do not agree. $10 \%$ of the respondents are unable to decide.

The last item, item 5 was about whether the grammar activities are suitable to discuss in pair/group and 
individually or not. For this item, $10 \%$ and $12.5 \%$ of the participants responded strongly agree, and agree, and $47.5 \%$ and $27.5 \%$ responded disagree and strongly disagree respectively while $2.5 \%$ are unable to decide. Based on the findings, it is possible to conclude that the grammar activities in the textbookcould not give students the chance to discuss in pairs/groups, which in turn negatively affects the practice of oral communication.

Analysis of teachers'interview regarding the appropriatenessof grammar activities

In this study, six teachers were asked five interview questions each. The first itemwas about the meaningfulness and purposefulness of the grammar activities in allowing students to use the language outside the classroom. Here the respondents ( $\mathrm{T}$ teacher hereafter) T1, T2, T4 and T6 asserted that most of the grammar activities in the textbook are not meaningful and purposeful in making the students use the language outside the classroom. Whereas, (T3, T5) said that some of the grammar activities are meaningful and purposeful to use the language outside the classroom. Their responses are more or less similar but expressed in the other way round. Student participants also confirmed this by their response in the third question of the students' questionnaire.

The second question teachers were asked was in relation to whether the grammar activities are authentic in eliciting real communication by allowing students to use language outside the classroom or not. For this question except T4 who replied that some of the grammar activities are authentic in eliciting real communication by making the students to use language outside the classroom the remaining five teachers (T1, T2,T3,T5, and T6) said that the activities are non-authentic.Therefore, it is possible to arguethat the grammar activities are non-authentic in eliciting real communication by allowing students to use the language outside the classroom.

Respondents were also asked the question "Do you think the grammar activities are designed to teach meaning rather than language forms?" Majority of them $(\mathrm{T} 1, \mathrm{~T} 2, \mathrm{~T} 5, \mathrm{~T} 6)$ answered that most of the grammar activities in the textbook are designed to teach language forms only whereas,T3,T4 commented that the grammar activities in the students' textbook are designed to teach meaning rather than language forms and able to encourage students to learn the form of the target language through meaning making.Hence, grammar activities in the textbook mentioned are said to be form oriented than meaning.

The fourth question, "Do you think the grammar tasks are integrated with the other language skills like reading, listening and speaking?" was intended to ask whether there is skills integration or not. As a result, still majority of teacher participants (T1, T3, T4, T5) explained that grammar activities in the text are well integrated with other language skills like reading, listening, writing and speaking. That means, the grammar activities take inputs from reading and listening texts in order to guide students with enough information. On the other hand, two respondents (T2, T6) said that grammar tasks are not integrated with other language skills and the text merely focuses on the form of the verbs. Therefore, with regard to integration of grammar with other skills is not a problem observed in grade eleven English textbook

The last question, which reads, "Do you think the grammar activities in the text book are suitable for doing in pair/group?" For this question also, five of teacher respondents (T1,T2, T3, T4, T6) replied that the grammar activities are not suitable for pair/group work, it does not give opportunities of group discussion;whereas, T5 said that some of the grammar activities are appropriate/suitable and others are not suitable. Therefore, one can deduce that in grade eleven English textbook, most of the grammar activities are not suitable for pair/group work.

\section{CONCLUSIONS AND RECOMMENDATIONS}

\section{Conclusions}

The main objective of this study was to evaluate the appropriateness of the grammar activities in grade eleven English for Ethiopia students' textbook in developing students' oral communication skills. 
Grammar tasks were identified and analyzed based onNunan's (1989) framework for evaluating tasks in textbooks. The findings hence revealed that the objectives of the grammar tasks are stated explicitly in a way that students could understand them easily. However, most of the objectives are not found as expected because of lack of variety and repetition. Though the grammar activities are appropriate to the goals of the tasks, most of the inputs in the textbook are not authentic and motivating. Most of the grammar tasks are also designed to be done in the classroom as well as outside the classroom setting but they are inappropriate for pair/group work to allow students to actively participate in-group. Moreover, the grammar tasks in the textbook are integrated with the other language skills. Most of the grammar tasks in the textbook are not appropriate to encourage language use/meaning rather they are focusing on form/structure. It was also found out that grammar activities in the textbook are giving little attention for pair and group work, and the activities are not at the expected level to encourage students' participation and develop their oral communication skill. Furthermore, the grammar tasks in the textbook are integrated with other language skills like reading, speaking, listening, and writing most of which are intended to emphasize verb forms.

\section{Recommendations}

Based on the above findings and conclusions, the following recommendations are made.

- The grammar tasks should be designed so as to encourage students to cooperate and communicate particularly in pair and in groups inside/outside the classroom.

- Material developers and textbook writers should consider grammar as one of the five basic components of tasks (goals, inputs, activities, roles and settings) when they design grammar tasks in the textbook or material.

- Authentic materials need to be incorporated in to the grammar tasks in order to make the activities more motivating and interesting.

- In order to practice and develop students oral communication skills in grammar, it should be good to forward some grammar activities are visual, dramatic, real object (authentic).

- Teachers should make some adjustments on the grammar tasks when the students come up with any confusion and enable them to motivate in the teaching of grammar activities.

- Moreover, doing further research should be important on the area of evaluating ELT material (particularly textbook) evaluation considering other language skills.

\section{REFERENCES}

Chambers, F.(1991). 'Seeking consensus in course book evaluation'ELT journal. Vol. 51/1

Cunnings worth,A. (1995). Choosing your course book. London: Macmillan Heineman.

Ellis, R. (1997). SLA research and language teaching. Oxford: Oxford University Press.

Harmer, J. (1991). The practice of English language teaching (new edition). New York: Longman group UK Ltd.

Larsen-Freeman, D. (2001) Grammar. In: Carter, N. and Nunan, D. (Eds.) The Cambridge Guide to Teaching English to Speakers of Other Languages. Cambridge, CUP, pp. 34-41.

Nunan, D. (1989). Designing Tasks for communicative Classroom. Cambridge: Cambridge University Press.

Nunan, D. (1991). Communicative Tasks and the Language Curriculum. TESOL, Quarterly, 25/2, 279-296.

Tiglu, G. (2008). The study of the appropriateness of communicative grammar teaching at grade 10. (Unpublished MA thesis). Addis Ababa, AAU.

Tomlinson, B. (1998). Glossary of basic terms for materials development in language teaching and introduction. In B. Tomlinson (ed.), Materials development in language teaching. Cambridge: CUP.

Wodajo, K. (2014). Evaluation of grammar lessons in grade ten English textbook in terms of developing of students' communication skills. (Unpublished MA. Thesis). Haramaya University. 